\title{
Realismeformer i Todd Solondz' Happiness og Paul Thomas Andersons Magnolia
}

\section{Indledning}

I Sam Mendes' film American Beauty er der en scene, hvor filmens to unge, Ricky og Jane, sidder på hans værelse, og hvor han filmer hende med det videokamera, som altid følger ham. Vi ser først Jane i et videokornet nærbillede, som fylder hele lærredet. »Lad være«, siger hun ud mod kameraet, og som forklaring på hendes vægring mod at blive filmet, „I don't like the way I look«. Derefter zoomer kameraet lidt ud, hvorved det afdækker en smule af værelset, og Jane rejser sig op i billedets nedre højre hjørne, simultant med at hun rejser sig op på videobilledet i baggrunden. Kameraet zoomer langsomt en smule videre ud og afdækker Ricky, som med bar overkrop og det filmende videokamera står i billedets venstre side. Jane tager kameraet fra ham, og indstillingen viser nu Jane bagfra med videokameraets lille monitor ca. i midten af billedrammen til venstre for hendes ansigt. I billedets venstre side står Ricky, og i billedets højre side afbildes han på en tv-skærm, hvis afbildning af ham, efter at Jane har justeret afstanden, er næsten identisk med det, vi ser i venstre side af billedet. "You don't feel naked?« spørger hun i næste indstilling, som i et nærbillede halvt forfra viser hende kigge ind i videosøgeren. Og i den tredie indstilling ser man Ricky på værelsets tv-skærm i et nærbillede kigge ned ad sig selv og sige »I am naked«, mens Jane står i forgrunden af filmbilledet og stadig kigger ind i videokameraets søger. Derefter beder hun ham fortælle om, da han var indlagt på et psykiatrisk hospital.

I denne elegante scene, der hele tiden implicerer kameraer og spørgsmål om repræsentationer og sandheder, bliver videobillederne privilegerede. De 
bliver både et tegn på og et middel til at skabe en oplevelse af autenticitet og sandhed, for både samtalen og scenens form implicerer, at sandheden lige så vel ligger i de kornede videobilleder som i den 'virkelighed', de afbilder; ja videobilleder kan kolportere en fornemmelse af sandhed, som ikke ellers kan fanges. Videobillederne er ikke erstatning for virkeligheden eller et værn mod virkeligheden, men en måde at komme i kontakt med den på og se den på. Privilegeringen af videobillederne knyttes i filmen til de unge. Men det bliver også klart i filmens slutning, at det, der i én kontekst er én sandhed, i den næste kan blive vidnesbyrd om noget helt andet, idet videobåndet i den efterfølgende historie om opklaringen af mordet på Lester, som filmen lægger op til, ville kunne bruges som et bevis på, at det er Ricky og Jane, der har skudt hendes far. ${ }^{1}$ Ricky siger, at videooptagelserne hjælper ham med at huske; men netop det, at de kan dekontekstualiseres og blive bærer af en anden sandhed, gør, at filmen ikke tildeler dem en almen sandhedsstatus. Videobillederne bliver bærer af lokale sandheder og for Jane og Ricky minder om et betydningsfuldt øjeblik.

Under creditsekvensens montage mellem filmens personer i Paul Thomas Andersons Magnolia ser man, på lignende vis, på en tv-skærm quiz show-værten Jimmy Gator blive hyldet som »an American legend and a true television icon«. Disse tv-billeder følges senere af en indstilling, hvor Jimmy til en lægesekretær præsenterer sig med ordene »I’m Jimmy Gator«; men filmen hierarkiserer ikke de to præsentationer - de er begge rigtige - og de er sideordnede repræsentationer i Magnolias realisme. Ved i Magnolia at have optagelsen af quiz-programmet What Do Kids Know som en plot-linje og vise produktionsprocessen på én gang som et menneskeligt drama og en kynisk rutine synes det at være Andersons bestræbelse at eliminere eller stille spørgsmålstegn ved forskellen mellem produkt og proces, den før-filmiske og den filmiske »virkelighed«. Filmen og tv repræsenterer ikke virkeligheden, de præsenterer den heller ikke, men er en del af den. Herved adskiller Andersons film sig fra typisk 1980'ernes og tidlig90'ernes film, hvor refleksivitet og intertekstualitet indgik i en tekst- og tegnproblematik eller hvor det i det mindste blev fortolket sådan.

Jeg ser disse to eksempler som udtryk for en kunstnerisk bestræbelse med virkelighedens materiale i en række nyere film eller en holdning i en række nyere film til sig selv og de levende billeder som repræsentationssystemer i det hele taget. Det er film, der på forskellig vis gør opmærksom på sig

1. I et interview i Sight and Sound, January 2001 gør Mendes opmærksom på, at filmen oprindelig havde et narrativt efterspil: arrestationer, scener i retssalen osv. Men de blev fjernet i den endelige version. 
selv som »realisme«, og som næsten bestiller en forståelse af sig selv som film, der gengiver virkeligheden realistisk. Det er samtidig film, der ikke formulerer en sammenhængende og autoritativ opfattelse af virkeligheden, men snarere på forskellig vis bevidst er konfuse, uden overblik og faste bud på betydningsmæssige sammenhænge og narrative hierarkier. Som i diskussionerne om modernismen er den nutidige filmiske realisme et spørgsmål om stil, om hvilke former vi som læsere/lyttere/seere - i sidste ende - godtager som former, der rammer os og giver adgang til en fornemmelse af realiteten.

Jeg skal i det følgende diskutere to ganske forskellige amerikanske independent film fra slutningen af 1990'erne som eksempler på nye former for realisme, nemlig Todd Solondz' Happiness fra 1999 og Paul Thomas Andersons Magnolia fra 1999. Den første foregår omkring tre søstre, deres familier og andre af de mennesker, de omgås i et grimt og usofistikeret New Jerseymiljø. Den sidste handler om en gruppe personer, hvis liv i løbet af et døgn spindes sammen omkring et tv-program, et quiz show og to dødsfald i San Fernando Valley, Los Angeles. Jeg ser de to film som eksempler på en realisme, som ikke er transparent, som ikke har nogen forestilling om, efter hvilke mønstre en nutidig virkelighed er ordnet, men som alligevel vil formidle en fornemmelse af virkelighed, som blander meget forskellige æstetiske udtryk for at nærme sig denne virkelighed, og som også benytter sig af udtryk, der ikke traditionelt bliver forbundet med realismen som repræsentationsform.

\section{Realisme}

Julia Hallam gør opmærksom på, at termen realisme i filmvidenskaben altid har været brugt til at markere, hvad der har manglet $i$ andre samtidige stilarter. $^{2}$ En pointe i forhold til realismeformer i 1990 'erne er imidlertid, at de ikke står i absolut kontrast til 1980'ernes postmoderne tekstualitet, men inkorporerer postmodernismens landvindinger, samtidig med at de skaber en anden æstetisk oplevelse. Således bliver noget af det, der karakteriserer det sidste årtis realismeformer, som Julia Hallam også gør opmærksom på, eklekticismen i realismen som stil, og, som hun siger, at vi må se realisme som noget lokalt og historisk specifikt. Derfor, siger hun, må man næsten altid tale om realisme med et præfix - neo-realisme, kitchen-sink realisme, dogmerealisme, traumatisk realisme etc. De nye realismeformer markerer

2. Julia Hallam: Realism and Popular Cinema, Manchester \& New York 2000. 
ikke nogen repræsentationskrise. De ser ikke realismen som et umuligt projekt post postmodernismen, men er snarere klare over, at en ændret opfattelse af realiteten kræver nye måder at producere realitetseffekt på.

Jeg skal i den følgende diskussion af de to film trække på pointer om en ny realisme, som den tyske professor i amerikansk litteratur, Winfried Fluck, leverer i en artikel om neo-realisme i ny amerikansk fiktion. ${ }^{3}$ Han analyserer bl.a. fiktion af Raymond Carver og Don DeLillo, og det er naturligvis evident, at hans pointer ikke uden videre kan overføres på filmmediet. Men for det første fremfører han en række interessante betragtninger om realismen som æstetisk nutidig form, som rækker ud over litteraturen, for det andet fremanalyserer han i sine læsninger af de amerikanske forfattere nogle æstetiske strategier, som jeg finder i lignende former i de to films audiovisuelle udtryk.

Overordnet er det Flucks pointe, at den nye realisme ikke gør krav på at kende realiteten i bestemt form. Det er ikke en realisme, der abonnerer på repræsentativitet og taler på baggrund af en erfaringens autoritet:

"It is a realism that does not claim to know the real, but wants to come to terms with the fact that it is nevertheless there in an amorphous, ever changing shape. In the final analysis, this realism refers us to a cultural situation whose complexity and variety can no longer be represented by any single text or mode of writing, only by a set of relations within a growing plurality of cultural styles and modes of writing. This new cultural space still has to be mapped out and in this sense a discussion of the new realism is meant to contribute to an understanding of the plurality of choices in which we currently live«. ${ }^{4}$

Det betyder, at hverken den klassiske realismes/naturalismes social-biologiske determination, neo-realismens opfattelse af, at den har erobret virkeligheden, eller socialrealismens beskrivelse af, hvordan mennesket indgår i komplicerede udvekslinger med sine sociale omgivelser, i dag kan gøre krav på formen for realisme. For ingen realismeform kan i dag rumme den autoritet, som implicit ligger i disse forståelser af realismen. ${ }^{5}$ Realismen negerer da i en vis forstand sig selv som begreb. Den kan ikke forstås som en -isme, men som en række strategier, hvorigennem filmsproget påberåber sig at tilbyde en version af realiteten. Hvor filmhistorien har fostret en række

3. Winfried Fluck: »Surface Knowledge and »Deep« Knowledge: The New Realism in American Fiction", in Kristiaan Versluys (red.) Neo-Realism in Contemporary American Fiction. Postmodern Studies 5, Amsterdam \& Atlanta 1992.

4. Op.cit., p. 85. 
forskellige realismeformer på forskellige historiske tidspunkter, er forskellige former i dag sameksisterende svarende til at realiteten er der »in an amorphous, ever changing shape«.

Realisme er, siger Fluck,

"a symbolic construct of reality designed to produce a certain effect called 'the reality effect' by Roland Barthes - in order to influence a culture's view of, consensus on, what is valid knowledge about the real [...] In this sense, realism is no more (and no less) than a system of rhetorical strategies in order to claim special authority for one's own interpretation of reality. It does not simply reflect or mirror reality, but offers a version of it, based on certain assumptions about the nature of the real and the best way of gaining knowledge about it. However, since these assumptions change, realism is at the same time also a form of writing that is in constant exploration of the real - which explains why we have a history of different realisms in literature with their own changing forms and functions $\ll{ }^{6}$

Den nye realisme er ikke bundet til virkelighedsefterligning i formel forstand. Den vil ikke mimetisk skabe overensstemmelse mellem tegnene og verden, fordi den i en vis forstand ikke ved, hvordan verden ser ud. Dens bestræbelse er snarere at afsøge former, hvori vi på nuværende tidspunkt kan godtage de fiktive fremstillinger som realistiske, jvf. Barthes' realitetseffekt.

Når Fluck siger, at den nye realisme tilbyder »en version af« realiteten, kan man indvende, at det har både realismen og andre formelle systemer til enhver tid gjort. Men pointen er her, at realisme i dag hverken kan formidle en overordnet forståelse af, hvordan virkeligheden hænger sammen, eller være egentlig realistisk, repræsentere virkeligheden som sådan. Den kan derimod gå i dialog med de til enhver tid eksisterende forestillinger om virkelighedens beskaffenhed, ligesom den kan udforske, hvordan den selv kan fremstille disse forestillinger i en form, der fastholder en 'realistisk', virkelighedsefterlignende repræsentationsmodus. Og de æstetiske fremstillinger kan inkorporere deres egen realitetsstatus i denne diskussion som en del af

5. Slutningen af Saturday Night and Sunday Morning er emblematisk for denne autoritative fremstilling af forbindelsen mellem menneske og sociale omstændigheder. Kameraet hæver sig over marken, hvor hovedpersonen og hans kæreste befinder sig for at vise en udkant af den midtengelske industriby, som han er udrundet af og, antyder totalbilledet, vil blive fastholdt i.

6. Ibid., p. 67 
det, de sætter sig for at udforske. Således er realismen i en række nyere film forbundet med diskussioner om film, repræsentation og realitet.

Både Magnolia og Boogie Nights, Paul Thomas Andersons forrige film, kan i én forstand siges at være metafilm eller selvrefleksive film. I Boogie Nights, som handler om pornobranchen i slutningen af 1970'erne og starten af 1980'erne, ser vi pornofilm blive optaget, i Magnolia et quiz show. I begge film ser vi også glimt af det færdige resultat, og der refereres gentagne gange til film i Magnolia både direkte og indirekte. Men det særlige ved Andersons film er, at refleksiviteten ikke som en palimpsestform bruges til at gøre opmærksom på det filmiske og det fiktive. Refleksiviteten bruges heller ikke til på postmoderne vis at problematisere, at virkeligheden er til, men snarere som et moment i en visuel og narrativ strategi, der skal betone, både at film altid allerede er en del af realiteten, og til at spørge, i hvilke former vi kan godtage fiktionen som realisme. I det hele taget bruger Anderson en række cinematografiske teknikker, der normalt skal skabe distance til illusionen og gøre opmærksom på, at dette ikke er andet end endnu en fiktion, til netop at bringe tilskueren tættere på det han laver og sige, at film ganske vist er et bestemt repræsentationssystem, men netop som sådant kan pege på realiteten. I den forstand tilhører Paul Thomas Anderson en generation af instruktører, for hvem film er en del af virkeligheden, og for hvem hele metaproblematikken stiller sig på en radikalt anden måde end for medieskeptiske instruktører fra den forrige generation som f.eks. Wim Wenders eller for den sags skyld for en samtidig instruktør som Quentin Tarantino, som snarere er interesseret $i$ at forholde sig til filmgenrer. Anderson siger således, at

"I hope my film is both very movie-wise and very reality-wise. I don't think you can pretend you haven't seen a movie if you're a director - I think part of my job is to acknowledge how many movies I've seen and how much that informs our lives. Movies are a big influence on how we deal with death, with family relationships, and I wanted to show that. But they can also be a complete betrayal in terms of how to live your life«. ${ }^{7}$

Hos Anderson er film altså ikke bare i bedste fald et system, der kan formidle oplevelser af virkelighed, men selv en del af feltet for autentiske oplevelser. Lige som hos Sam Mendes.

I sin læsning af Carver og DeLillos prosa når Fluck frem til, at deres realisme beskriver personer, som ikke så meget er følelsesmæssigt sårede som

7. Sight and Sound, March 2000. 
"confused, unstable, and desoriented «. ${ }^{8}$ Kriser og katastrofer bliver ikke fremstillet som fundamentalt ændrende hændelser i personernes liv, de er ikke "heroic moments" og har ingen "redeeming force of initiation or transformative potential for the weak identities", men personerne skrives ind i en strøm af sideordnede begivenheder, hvor det banale og det usædvanlige har samme status. ${ }^{9}$ Realiteten bliver reduceret til "moments of decontextualized experience. $\|^{10}$ Dekontekstualisering og dehierarkisering er de centrale begreber i Flucks konceptualisering af Raymond Carvers æstetiske strategi. Realiteten iscenesættes symbolsk som en række af dekontekstualiserede øjeblikke i en slags cool 'overfladerealisme', hvor hændelser og personers reaktioner ikke tilføres så megen information, at man kan se dem som fremtrædelser for dybere eller bredere psykologiske eller sociale mekanismer. Således svinger de i et æstetisk felt mellem at referere til realiteten og at negere den form for autentificerende generaliseringer, repræsentative erfaringsformidlinger, som realismen traditionelt abonnerer på:

»Carver needs realism to establish a promise that provides his stories with potential meaning, and, thus, with interest. But his narrative technique of metonymic minimalism remains without a representative center or depth because the relation between sign and referent has become so unstable and transient that his signs are constantly placed in states of isolation and decontextualization «. ${ }^{11}$

'Metonymisk minimalisme' kan synes en selvmodsigelse, i hvert fald hvis man med Torben Grodal bl.a. opfatter (den klassiske) realisme som simuleringen af en lighed med en »åben-uafgrænset og urettet verden", hvor et objekt eller et træk er forbundet med andre objekter eller træk »ved et væv af metonymiske forbindelser«, og hvor udvælgelsen af elementerne "synes at være gjort tilfældigt«. ${ }^{12}$ Men for det første henleder betegnelsen opmærksomheden på, at Fluck taler om verbalsproglige fremstillinger, der har langt større mulighed, end filmsproget naturligvis har for at konstruere minimalisme. For det andet kan betegnelsen også i en diskussion af filmrealisme bruges til at betone, at den nye realisme både er traditionel virkelighedsillusion, baseret på metonymiske forbindelser og en virkelighedsfremstilling, som giver afkald på den mimetiske fylde, der straks siger 'realisme'.

8. Fluck op.cit., p. 70-71.

9. $\quad$ Fluck op.cit., p. 72.

10. Ibid., p.73.

11. Ibid., p.78.

12. Torben Grodal: »Indramning, intertekst og tv-fiktion«, Mediekultur 14 (1990), p. 84. 


\section{Todd Solondz' Happiness}

Jo mindre emotionelt og sentimentalt, jo mere distanceret en tekst præsenterer sig, jo mere må den dekontekstualisere sit materiale, siger Fluck. Det forekommer mig, at såvel denne bemærkning som forestillingen om dekontekstualisering og dehierarkisering, om overflade og om den manglende erfaringstematisering eller psykologiske opskrivning af personlige kriser er relevante - om end de ikke er udtømmende - i forhold til en beskrivelse af Happiness som realistisk tekst. Det synes, som om netop det, at Solondz lader en af sine hovedpersoner være en psykiater, der jo i sin profession opererer med en vertikal vidensstruktur, bliver brugt til at understrege overfladerealismen og dekontekstualiseringen i filmen. Pointen er ikke bare, at denne psykolog mindst af alt har styr på sig selv og sit indre - eller underste; han har en ustyrlig hang til drenge og bliver til sidst arresteret efter at have voldtaget to af sin søns skolekammerater. Han er en 'serial rapist', som der står sprayet hen over facaden på familiens hus til sidst, fanget i en gentagelsesstruktur. Pointen er snarere, at det indre ikke er forskelligt fra det ydre i filmen. Der er ingen dyb viden, ingen samlende forklaring eller et skjult mønster, som giver mening til hans handlinger. Da den ulykkelige fader til sidst skal svare på sin ulykkelige søns spørgsmål om sine lyster, lyder ordvekslingen (i en pinagtigt dvælende krydsklipning mellem langsomme spørgsmål og svar, mens tårerne løber ned ad kinderne på både sønnen og faderen, som hele tiden kigger intenst på sin søn):

Sønnen: What did you do?

Faderen: ... I touched them.

Sønnen: What do you mean, like touched?

Faderen: ... I fondled them.

Sønnen: What for?

Faderen: I couldn't help myself.

Sønnen: What else?

Faderen: ... I unzipped myself.

Sønnen: You mean masturbating?

Faderen: ... No.

Sønnen: Then what?

Faderen: ... I made love.

Sønnen: What do you mean?

Faderen: ... I fucked them.

Sønnen: What was it like?

Faderen: ... It was great. 
Sønnen: Would you do it again?

Faderen: ... Yes.

Sønnen: Would you ever fuck me?

Faderen: ... No ... I jerk off instead.

Faderen svarer lige så direkte, konkret og usentimentalt, som sønnen spørger; men han skaber ingen sammenhæng for sønnen, og han kommunikerer ingen udveksling eller forståelse. Samtalen skaber ingen forandring og ingen forløsning, for den fører ikke frem til en form for existentiel sandhed. Faderens svar er blot endnu en repetition på et andet niveau, en verbal jerking off, der både refererer til den omtalte handling og ikke gør det. I Solondz' 'cool' realisme er sandheden ikke traumatisk gemt, og sproget skal derfor ikke kæmpe med at få den frem. Sandheden er ikke det indres åbenbarede røst, den samlende erfarings tale, men en gengivelse af en dekontekstualiseret oplevelse, der af den grund ikke danner ar i kroppen. Der er ingen forløsning i talen, for der er ingen rensende erkendelse - der er ikke noget indre, der kan virke ændrende ind på det ydre; det er det uhyggelige i denne scene fra en postfreudiansk kultur.

Sandheden kan udtales som brutalt konkrete fremsættende sætninger "you've been fuckin' raped", som faderen til en af de voldtagne drenge uden omsvøb siger til sin søn. Og talen er direkte og cool, da Trish siger til lillesøsteren Joy, at hun altid har opfattet hende som »doomed to failure«, eller da Christina på diner'en tilstår mordet på dørmanden overfor sin nabo Allan og konkret beretter, at hun »cut up his body« og puttede delene i plasticposer "I've been throwing out ever since - there's still some left in my freezer" samtidig med at hun koldsindigt tager en bid af sin isanretning og i samme åndedrag spørger, om de kan forblive venner.

Todd Solondz' Suburbia er ikke et rart sted at befinde sig - det er hans familier heller ikke. Hos Solondz er såvel familien som kroppen og seksualiteten et fængsel. Både Happiness og Solondz' forrige film Welcome to the Doll House (1996) indeholder et veritabelt katalog over middelklassemonstrøsitet og seksuel frustrerethed. Men i modsætning til de mange film om den dysfunktionelle familie, som den nyere filmhistorie indeholder, hvor psykologiske mønstre, årsagsforklaringer og lig i lasten på bedste klassisk realistiske vis står i centrum, er Solondz' kølige og distancerede realisme blottet for psykologi og for forsøg på at give forklaringer. Solondz er fuldstændig usentimental. Han beskriver nøgternt og lidenskabsløst mennesker uden emotionelle bånd eller med længsler efter at skabe en nærhed til andre, som de ikke er i stand til at indfri, mennesker uden empati, der blot episodisk indgår i relationer til hinanden. Men samtidig er denne lakoniske 
dekontekstualisering af personerne også baggrunden for filmens grumme og groteske humor og dens skabelse af en række næsten surreelle situationer, i overensstemmelse med at Winfried Fluck gør opmærksom på, at

"the more independent the linguistic or visual material becomes, however, the greater the likelihood that it will acquire its own surreal presence and thus transform the nature of the aesthetic experience.$^{13}$

Grotesken eller det surreelle bliver dermed en del af denne form for dekontekstualiserende realisme, så at sige en form som den selv aftvinger, fordi begivenheder ude af kontekst pludselig kan få deres eget absurde liv. Det groteske og absurde er elementer, som ikke traditionelt opfattes som realistiske, men som her bliver vigtige elementer i skabelsen af det momentane "sharp-focus« billede, som Fluck kalder det, næsten surreelt og dog bibringende en stærk fornemmelse af realitet. ${ }^{14}$ Scenen med Christina og Allan på diner'en er et eksempel på denne groteske humor. Christinas fortælling er uden hierarkiserende ordning. Hun fortæller på samme niveau, at hun glædede sig til at pakke sine indkøb ud og "get under the covers and watch tv«, og så hvordan hun knækkede halsen på den lille dørmand, der hjalp hende op med varerne og blev lidt for bjergtaget af den store kvinde. Isanretningen på tallerkenen skaber heller ikke associationer hos hende til fryserens indhold derhjemme, endsige til at hun serverede en portion is for dørmanden, inden han kastede sig over hende, og hun kvalte ham. Den banale, hverdagslige situation og det dramatiske og grænseoverskridende, hun fortæller om, støder sammen. Det gør ligeledes hendes næsten tilfældige tale og hendes afsluttende bemærkning om, at hendes handling var en »crime of passion. I'm a passionate woman« - hvorefter hun roligt tager endnu en bid af isen.

Den 'cool' overfladerealisme understreges endelig i benægtelsen af, at liv og kunst hænger sammen, at en indre dybde giver sig ydre autentiske udtryk i skabende virksomhed. To af de tre søstre, Joy og Helen, repræsenterer henholdsvis den sentimentale tro på, at de kunstneriske udtryk er autentiske fremstillinger af det indre, og den kyniske bevidsthed om, at det ikke er tilfældet. Joy synes ude af stand til at gebærde sig, fordi hun tror, at liv og kunst falder sammen, at sange kommer fra det indre. Hun lader sig forføre af den tyvagtige og svigefulde russiske immigrant Vlad, fordi han synger en sang til hende - om hende, tror hun også - om "you light up my life« - mens forfatteren Helen, der har skrevet digtsamlingen Pornographic Childhood,

13. Fluck, op.cit., p. 74

14. Ibid., p. 69 og 79. 
ikke har noget at have titlen i og ler foragteligt, da Joy, efter at Helen har underholdt sin familie med naboen Christinas skæbne, ytrer, at Helen kan skrive et digt om det, hun har oplevet.

Men ud over denne cool nutidsrealisme er der i figurtegningen i Happiness elementer af såvel 1970'ernes superrealisme som spor af den type realisme, kunsthistorikeren Hal Foster har kaldt for traumatisk realisme ${ }^{15}$ for at betegne en kunstnerisk bestræbelse i 1990'erne på at lave værker, der rammer os med affekt. Den traumatiske realisme findes i Happiness i de abjektale aflejringer, som filmen ikke viser, men som vi hører om: lorten og blodet der afslører, at nogen har forgrebet sig på et par drenge, dørmandens parterede lemmer, eller sæden, der som en slimet klat sprøjtes ud på en væg eller et rækværk. Den traumatiske realisme kan også lokaliseres i den del af sproget, der ikke er konkret og cool - i aggressionerne og fantasierne, f.eks. i de rasende udladninger i telefonen eller til psykologen når Allan forestiller sig, hvordan han vil kneppe Helen sønder og sammen. Og den kan forbindes til de perverse lyster, pædofilien, som en struktur, der momentant - ulykkeligt - foranlediger en rift i den skærm (screen), der skaber mennesket i dens billede. Den traumatiske realisme udtrykkes endelig også i dødens nærvær, i Joys kærestes selvmord, i angsten for døden der maskeres i de ansigtsløftninger, der for en stakket stund kan forbinde pigernes depressive mor med de kulturelt foreskrevne billeder, angsten for at være alene, for at dø alene.

Duane Hansons hyperrealistiske menneskeskulpturer rinder en i hu, når man ser Todd Solondz' film, ikke så meget fordi Solondz' univers er befolket af overvægtige husmødre iført papilotter og indkøbsvogn, udslidte, sammensunkne lønarbejdere, narkomaner eller sovende bumser, som fordi hans måde at beskrive mennesker på minutiøst konkret minder om Hansons. Hos Solondz blandes to former for overfladerealisme, en realisme der har givet afkald på at være andet end overflade, og en realisme, der forsøger at fremstille typen i det individuelle. Britta Timm Knudsen skriver meget præcist om superrealismen eller hyperrealismen i Duanes skulpturer:

"... det hyperrealistiske går på deres billedkarakter. De er netop ikke reelle (forstået som traumatiske), men de er hyperreelle, fordi realismen i dem er faldet sammen med sit billede. Hvis vi overfører dette til kroppen - og det er ofte kroppen der portrætteres i Hansons idealtyper - så er det skulpturer, hvori det overpersonale og de helt personlige særtræk er smeltet sammen. Der er ingen forskel, og dette træk gør skulpturerne uhyggelige. De superreelle eller hyperreelle skulpturer viser, hvorledes

15. Hal Foster: The Return of the Real, Cambridge \& London 1996. 
billedet og lærredet (image/screen) slår ind på kroppen, standardiserer den. $\ll^{16}$

I Hansons illusionistiske, stiliseret-menneskelige figurer falder den omhyggeligt skabte individualitet i figurerne fuldstændig sammen med en tilsvarende omhyggeligt skabt typificering. På én gang synes de så menneskeligt levende, at man får lyst til at tale til dem, og så fremstår de i al deres typificerede stivnethed samtidig som livløse billeder. Som kunstværker fremtræder de konkret-almene, som en »konstrueret syntese « ${ }^{17}$ skabt på baggrund af oplevelsen af en konkret menneskelig model og en forestillet typologi. Hanson arbejdede således med levende modeller, som han interviewede og som poserede for ham, inden han startede på arbejdet med en skulptur. Hans værker er en kompliceret blanding af stereotyp, type og singularitet.

Superrealismen på én gang modsætter sig en tilnærmelse til det reelle og kommer uafvidende alligevel til at nærme sig det. Som (stereo)typer falder Hansons skulpturer sammen med det kulturelle billedrepertoire, hvorigennem vi betragter og skaber os selv (the screen som Britta Timm Knudsen kalder det med Kaja Silvermans gennemgang af Lacans synsmodel), ${ }^{18}$ men samtidig presser de, som Foster siger, illusionismen uhyggeligt op mod billedskærmens grænser, mod det groteske og dét skræmmende 'reelle', der er på den anden side. ${ }^{19}$ Superrealismen i 1970 'erne peger altså i en vis forstand frem mod 1990'ernes traumatiske realisme; men hos Solondz ligger det traumatiske som nævnt et andet sted. Solondz' superrealistiske karakterer tenderer alene mod (stereo)typen, inkarneret i den pæne, seksualforskrækkede husmor Trish, som kun kan håndtere normalitet og klare grænser, Christina med den store krop, flæsekjoler og sløjfer i håret, hvis soveværelse ligner et ungpigeværelse, eller Joy, der stadig bor i sit barndomshjem, og hvis værelse er fyldt med bamser.

Hansons superrealisme er autoritativ og kontekstorienteret - det er dialogen mellem kroppene og de elementer, rekvisitter fra det amerikanske varesamfund, der omgiver dem, som skaber en Hanson-skulptur, siger Kirk Varnedoe i samme sammenhæng, og de fremtræder som symbolske kommentarer til dette samfund og den eksistens, det tilbyder. Hanson har således selv i 1970 udtalt, at

16. Britta Timm Knudsen: Nye former for realisme? (Arbejdspapir 80, Center for Kulturforskning, Aarhus Universitet), Århus 2000.

17. Kirk Vanderhoe: Duane Hanson, New York 1985, p. 20.

18. Kaja Silverman: The Threshold of the Visible World, London \& New York 1996.

19. Foster op.cit., p. 141 og 152. 
»Tidligere havde jeg været mere interesseret i skulpturens formelle kvaliteter og havde forkastet emner der var alt for ekspressive og foruroligende. Nu finder jeg at form og udtryk i det, jeg laver styrker hinanden. Jeg er meget optaget af figurens gestik, modellering, skygger, overfladenuancer og tekstur, jeg prøver at fange virkeligheden uden at reproducere den. [...] Indholdet, emneområdet i mine skulpturer opstår af min følelse af desperation. Realismen er bedst egnet til at skildre vor tids frygtindgydende idiosynkrasier. Hensigten med det jeg laver, ligesom det blinkende færdselssignal, er at afbilde nogle af de latente og eksplicitte rædsler i det samfund, der omgiver os«. ${ }^{20}$

Men til forskel fra Hanson synes det snarere hos Solondz, som om figurerne og deres omgivelser falder sammen uden at gå i dialog med hinanden, uden at kontekstualisere hinanden, som når Christinas isdessert har nøjagtigt samme farve og mønster som hendes kjole og i hele beskrivelsen af den forlorne Florida-setting med whiskymuzak, der konstant akkompagnerer pensionisttilværelsen. Hvor Hansons figurer er blevet kaldt for satiriske, ${ }^{21}$ der er Solondz' snarere depressive; når Todd Solondz iscenesætter stereotyper, synes det mig som et depressivt forsøg på at vise, at enten falder mennesker og miljøer sammen med deres billede, eller også forsøger de at undvige det i en form, der kun kan være (selv)destruktiv.

\section{Paul Thomas Andersons Magnolia}

Paul Thomas Anderson lavede før Magnolia Boogie Nights (1997), som skulle blive hans meget roste gennembrudsfilm (efter Hard Eight-oprindelig Sydney - fra 1996), og selv om Magnolia er meget anderledes end både Hard Eight og Boogie Nights, er det tydeligvis nogle af de samme ting, der optager Anderson, som har skrevet manuskriptet til alle film. Den unge instruktør iscenesætter selvbevidst filmene som en 1990'ernes auteur, ikke blot gennem tydelige genkommende temaer, men også ved at bruge de samme skuespillere og hinte sammenhænge ved at lade karakterers navne gå igen. Navnet Jimmy Gator optræder således i Hard Eight som navnet på en ikke-kropsliggjort gangster, nævnt i en enkelt sætning. I den forstand er Paul Thomas Anderson en af de yngre amerikanske filminstruktører, der næsten fra den allerførste film installerer sig som auteurer i deres værker, som et

20. Louisiana Revy, 13. årgang nr. 3, februar 1973, p. 29.

21. Martin H. Bush: Duane Hanson, Wichita, Kansas 1976. 
independent-instruktørens tegn på autenticitet og kvalitet, men også som en cadeau til arven fra instruktører som John Cassavetes og Robert Altman.

Paul Thomas Anderson er optaget af familier og fædre. I Hard Eight, der foregår i kasinomiljøet i Reno (som, i parentes bemærket, også dukker op som lokalitet i en af indledningsvignetterne i Magnolia), er det den ældre Sydney, som tilsyneladende træder ud af nowhere, samler den unge John op og installerer sig som hans far, i Boogie Nights den alfaderlige pornofilminstruktør Jack Horner spillet af Burt Reynolds, og i Magnolia de to døende fædre, tv-producenten Earl Partridge og tv-værten Jimmy Gator. Ligeledes er Anderson optaget af forholdet mellem forældre/fædre og børn. Det gælder for debutfilmen Hard Eight, ligesom det er en meget tydelig tematik i Magnolia - den handler om børn med brændte englevinger, om voksne der forbliver børn - Donnie, der skal have bøjler på tænderne, til trods for at han, som det bliver sagt, har smukke tænder - eller om børn, der tænker som voksne. Anderson er optaget af maskuliniteten som maskerade og af skrøbelige subjekter, og så er han optaget af forholdet mellem film og virkelighed.

Det er i den forstand ikke så underligt, at han har lavet en film om pornoindustrien og pornofilm, der netop som omdrejningspunkt har forholdet mellem simulation og autenticitet. Pornofilminstruktøren Jack Horners projekt er dybest set at indfælde autentisk begær i pornofilmen, at skabe sand porno og dermed at skabe god porno. Han har fundet den ideelle krop, den unge Eddie Adams med den store pik og det umættelige begær, der døber sig om til Dirk Diggler, og som Jack Horner mener kan fremstå autentisk sexet og ikke bare mekanisk potent i film. Jack Horner vil altså nedbryde væggen mellem film og tilskuer; eliminere den ambivalens mellem 'sandt' og 'tilsyneladende', som altid følger pornofilmens iscenesættelser, ${ }^{22}$ gøre indekset altomfattende og igennem sammensmeltningen af virkelighed og performance skabe kunst. Men dette naive projekt er naturligvis dødsdømt. For den gentagelsesstruktur, som i Magnolia kan blive til kynisme (Jimmy Gator der er på sit 33. år som studievært; chefen på politistationen som siger bla bla bla, når han skal referere til de idealer, politiet arbejder efter) kommer også til at hjemsøge Jack Horners stjerne, samtidig med at virkeligheden fordrer sit for at blive »tilsyneladende« på skærmen.

22. Rune Gade taler om, at den fotografiske pornografis fascination ligger $\mathrm{i}$ »dens indeksikale natur, de spredte spor af en virkelig persons virkelige begær, der tilsyneladende vedvarende bryder frem gennem overfladen af fiktionens »dårlige» udførelse«. Jvf. Rune Gade: Staser, (Passepartouts Særskriftserie, Institut for Kunsthistorie, Aarhus Universitet) Århus 1997, p. 224. 
I Magnolia er seksualiteten blevet en privat affære og dens pornografiske og fotografiske momenter nedtonet. Seksualiteten er mere en verbalsproglig end en fysisk handling, og den er mere fortid end nutid. Fuck, cocksucker, cunt er ord, der ustandselig flyder ud af personernes mund, hvis da ikke coke går ind ad en anden åbning i kroppen, nemlig næseboret. I forhold til Boogie Nights er der sket en markant forskydning; fra kødet til ordet og fra kønsorganerne til andre sanseorganer. Tilsvarende er den virile og naive Dirk fra Boogie Nights i Magnolia afløst af Tom Cruises forførende Frank Mackey, der taler om, at sproget er »the magical key to unlock the female analytical mind«. Men også her er der sket en forskydning, idet Dirks krop intuitivt kunne teknikkerne, som han ikke havde ord for, mens Frank skal lære sine "students" på seminarerne dem og selv hele tiden formulerer sit virilitetsideal i sloganagtige sætninger. Hvor det historiske tidspunkt satte personernes handlinger i relief i Boogie Nights, dér mangler det forklarende perspektiv i Magnolia; karaktererne er historisk dekontekstualiserede, overladt til sig selv og deres personlige forhistorie. Hvor personerne i Boogie Nights har historiens nostalgiske påklædning som undskyldning for deres naivitet, der har de i Magnolia ingen for deres kynisme og deres forvirring.

Men hvilken slags realisme kan man så tale om i Magnolia? Man kan også her, og i meget mere bogstavelig forstand end i Happiness, tale om en traumatisk realisme: Om traumer, der spiller sig ud, men som ikke kan komme $u d$, og som derfor blot efterlader personerne uden forløsning i evige repetitioner. Om personer der så gerne vil tale, men som enten gør det alt for sent (Earl), eller ikke kan få sandheden over deres læber (Claudia), om et sprog der hele tiden forskyder sig fra det, det egentlig handler om, eller som skal tages i munden af andre. I Magnolia kan sandheder udtrykkes forskudt af den anden, og halve sandheder kan siges. Eller også kan sandheden slet ikke komme frem - den forbliver uigenkaldeligt et »I don’t know«, som Jimmy Gator siger som sine sidste ord, inden han skyder sig selv - adspurgt af sin kone om han faktisk forgreb sig på sin datter.

Resultaterne af, at sandheden er der i traumet, men at den er utilgængelig i andet end forskudt form, og at det indre derfor aldrig gives udtryk, får forskellige former i filmen; disse er dog alle knyttet til kroppen og til sproget, ikke fordi sandheden trænger igennem kroppen, men fordi kroppene, til forskel fra i Happiness, ikke falder fuldstændigt sammen med deres billede. Forskydningerne sætter sig som gentagelsens mærker uden på kroppen, i Claudias dirrende krop og de evige indtagelser af coke, i Lindas urolige, omkringfarende krop, i hendes halvt-artikulerede sprogbrug og i hendes medicinmisbrug, i Franks metalliske »hardbody« - som jeg skal komme tilbage til, kan man se Frank og Claudia som to modsatte kropslige udtryk for 
den samme problematik - og på Earls dødsmærkede krop, i leverpletterne på hænderne, i de grå skægstubbe, i de indfaldne kinder, i den lange kvalfuldt angrende monolog og i den uartikulerede mumlen, når han kun er halvt ved bevidsthed.

Kroppene taler altså, samtidig med at de ikke ved, hvad de taler om; referenten er forsvundet. Kroppene på en gang ønsker at tale og tie stille, under alle omstændigheder når de ikke sagens kerne. Eller den utilgængeliggjorte sandhed sætter sig som mærker inde $i$ kroppen, i dødsmærkningen af Earl og Jimmy, filmens to "masters«, patriarkerne, hvis storhed nu uigenkaldeligt står for fald, idet de begge er ved at dø af kræft. Sandheden er knyttet til døden, men i sidste ende også til dødeligheden og til fejlbarligheden som traumatiske størrelser.

I en indstilling, der ligger lige før, Earl får morfindråberne første gang (de dråber der, som Lindas læge siger, får »all signs of the recognizable Earl pretty much go away «), og efter at han har holdt sin tale/tilståelse om sin kone Lily og sine svigt som far og ægtemand, kigger han ud mod kameraet, som kunne dødens blik, lige før det bliver helt fremmed, inde fra kunstværket selv ramme os som et glimt af det reelle, eller nidstirre os i et kort sekund, som borede blikket sig som en smertende pil gennem lærredet, der ikke mere er transparent, men åbenbares som en skærm - endnu en skærm - der ikke mere adskiller os klart fra filmen. Earl gør med sit blik ikke opmærksom på sig selv som en fiktiv karakter, men på os som nogle der ligner ham, som nogle der er underlagt de samme vilkår som ham - dødelighedens skrøbelighed. I et kort nu hiver den døende figur os med til et sted, som er hverken-eller, på grænsen mellem liv og død inde i fiktionen og på én gang inde i og udenfor fiktionen; på én gang uhyggeligt »live« og hinsides. I dette ingenmandsland befinder den døde og døden sig; som filmen fremstiller det, er dødsøjeblikket det sted, hvor realiteten afløses af det reelles finale sandhed.

Et andet eksempel på en bryden igennem en orden, et forsøg på at bryde igennem skærmen i skærmen kan vi finde i scenerne med quiz show'et, hvor Stanley ødelægger quiz show-skemaet og uden om studieværten begynder at tale direkte til tilskuerne i studiet om at blive gjort til barne-freak. Denne destruktion af en symbolsk form kan lykkes, fordi show'et er live - det skaber hele balladen, det uforudsigelige, det "uncanny", "horror'en«, "the real« - det er nogle af de begreber, som tv-teoretikere har brugt, når de karakteriserer live-tv's potentielt katastrofiske muligheder. ${ }^{23}$

Men der er også en anden form for realisme på spil i filmen, som gives udtryk i den filmiske form og dens udsigelsesforhold, hvor fortællerniveauer hele tiden veksler næsten antitetisk mellem at være installeret i forskudt 
form inde i filmen, i filmens diegese som replikker, og så påfaldende tydeligt at markere sig som en dokumentarisk stemme helt udenfor, der dog samtidig omtaler sig selv som "this humble narrator" og taler om "humble opinions of this narrator«. Denne ydmyge fortæller finder vi i filmens start og slutning, hvor en fortællerstemme reflekterer over "stories of coincidence and chance and intersections and strange things told « - over at der ikke er noget, der hænger sammen, at der ikke eksisterer noget sammenbindende og helende sted - »and so it goes and so it goes", og som er helt i vildrede med, hvad han skal mene om disse historier, "this, please, cannot be that".

Denne problematisering af en autoritativ udsigelse var allerede tilstede i Boogie Night, der starter med, at vi ser filmens titelskilt i lysende neon. Det viser sig dog at være en diegetisk rekvisit, for da kameraet tilter sidelæns ned afsløres, at ordene er titlen på en film, der spilles i en biograf i San Fernando Valley, hvor filmen foregår - credits foldes altså diegetisk ind i filmen som dens første sekvens. Det er den samme udsigelsesmæssige figur, vi finder i Magnolia. Der er tale om en form for indfoldning af instruktørens mærker, der negerer en autorial autoritet ved på den ene side næsten ironisk at hypostasere en gammeldags fortæller, som ikke desto mindre er ganske usikker på, hvad det egentlig er, han ser og derfor dårligt kan fortælle, og på den anden side at lade diegesens karakterer overtage replikker i den realismediskussion, som føres overordnet af filmen. Jeg tænker på, at Anderson lader drengen Stanley sige »This happens. This is something that happens", da han ser frøerne falde fra himlen, eller instruktøren lader Phil sige i telefonen, at "I think they have these scenes in movies because they are true. Because they are really happening". Anderson lader hurtigt kameraet udpege titlen på et maleri, "But it did happen«, på væggen i Claudias lejlighed, og endelig lader han diegesens personer og den ekstradiegetiske fortæller udtale nøjagtig det samme, nemlig den sætning fortælleren slutter af med: "And the book says, we may be through with the past, but the past ain't through with us". For ikke at tale om, selvfølgelig, at han manipulerer den ekstradiegetiske musik (Aimee Mans "Wise Up«) ind i filmen og lader personerne synge den.

Indledningssekvensen består af tre historier fra tre forskellige tidspunkter i det 20. århundrede, genfortalt, "as reported" eller "told" bedyrer fortælleren. Den første, som foregår i 1911, er visualiseret i stumfilmens

23. Det er altså vigtigt i dette eksempel på en form for traumatisk realisme i Magnolia, at quiz show'et er live. Jvf. om disse metaforer og om live-tv: Anne Jerslev: Nu'ets affekt. Virkelighed, live-ness og katastrofisk intensitet i reality-tv, (Arbejdspapir 2 fra forskningsprojektet Realisme, realiteten, det reelle $i$ visuel optik), Århus 2000. 
sprog, den anden indledes fragmentarisk med at berette om tre elementer (en skovbrand, en sportsdykker og en flyvemaskine), som derefter bindes nødtørftigt sammen, mens fortælleren i den tredie nøgternt, dokumentarisk, med pile, frysning af filmens billeder og gentagelser forklarer om et forløb, der transformerede et selvmordsforsøg til et mord og den døde til medskyldig i mordet på sig selv. Ikke desto mindre, trods den minutiøse og gentagne redegørelse, er fortælleren afmægtig overfor det fortalte, som han ikke forstår en lyd af. Han slutter af med i affekt at sige, at "this is the humble opinion of this narrator that this is not just something that happened. This cannot be »one of those things«. This please »cannot be that««. Han udtaler åbent, at han ikke kan sætte ord på det eller finde en mening i det, men at »these strange things happen all the time«. Som dokumentarisk ikke-kropsliggjort fortællerstemme er denne fortæller ikke placeret i samme position som den traditionelle, autoritative. Han forsøger, han gør rede; men han kan ikke forstå, han kan ikke skabe sammenhæng, han kan ikke fortolke. I filmens epilog, hvor Earls døde legeme bæres ud af huset, kan fortælleren da også blot gøre opmærksom på et repetitionens sideordnende princip, "and so it goes and so it goes« og selv repetere, hvad andre allerede har sagt. Så det, vi finder her, er altså en række tydeliggjorte dekontekstualiserede momenter, om end de ikke sættes i scene hverken på samme cool distancerede måde som i Happiness eller cool minimalistisk som i Winfried Flucks litterære eksempler.

Derfor vil jeg foretrække at benævne den form, Paul Thomas Anderson her sætter sin film i scene gennem, med termen hysterisk realisme. Den hysteriske realisme kommer til udtryk i filmens overlæssede sprog, hvis niveauer hele tiden oscillerer betydningsmæssigt i forhold til hinanden uden et klart hierarki, i narrationen der ikke kan blive færdig (den former sig, som Earl siger om sin egen fortælling, som »a long way to go with no punch" dvs. ingen endegyldig sandhed), i gentagelserne, i de mange forskydninger i dialogen, i den parataktiske struktur, i filmens iscenesættelse af tid og rum og $\mathrm{i}$ iscenesættelsen af en række af personerne. Begrebsmæssigt refererer jeg her til Elizabeth Bronfens ideer om hysterien som umulig repræsentationsform. ${ }^{24}$ Det forbløffende er, hvor godt Bronfens diskussion passer på Magnolia - også selv om hendes egne filmeksempler overvejende er hentet fra film, der indeholder en psykoanalytisk diskurs (Hitchcocks Marnie og Psycho og Woody Allens Zelig f.eks.). Jeg trækker hendes pointer noget længere, end hun selv gør, idet jeg ikke ser hysterien som en tematisk størrelse og ikke

24. Elizabeth Bronfen: The Knotted Subject. Hysteria and its Discontents, Princeton, New Jersey 1998. 
bare knyttet til karaktererne, men ser den som et formelt princip, der i den forstand, mere end en psykoanalytisk kategori, bliver den symbolske form, som Magnolia tilbyder sin version af realiteten igennem. Som det vil fremgå af det følgende, kommer jeg heller ikke til at modsige mig selv og med begrebet indføre en dybdemodel i denne diskussion, der i øvrigt har fremhævet en dehierarkiserende og dekontekstualiserende realisme. En pointe i forhold til Bronfens diskussion af hysterien er jo, at hysteri netop ikke er i stand til at føre bevis for dybde, for sammenhæng og for en samlende forklaring.

Først kort om Bronfens nylæsning af den hysteriske lidelse, som hun flytter fra kønsmæssige determinationer og til dels også fra den somatiske lidelse til at forstå som billede på et alment forhold ved subjektiviteten. Der er enkelte bemærkninger i bogens første kapitel, som refererer til, at Bronfen ser hysterien som en form for oprør, lige som i den feministiske litteratur i årene omkring 1980; som udtryk for noget, der ikke restløst lader sig indordne i en patriarkalsk symbolsk orden. Men først og fremmest flytter Bronfen diskussionen fra den seksuelle etiologi til at koncentrere sig om traumet i almindelighed som den bagvedliggende årsag til hysterien, den årsag, der aldrig kan nås og bevises, situeret i det reelle som den er, den frygtelige erkendelse af dødelighed og tab. Hysterien er "en malady of representation«, som hun siger, ${ }^{25}$ et udtryk for et fejlslagent møde med det reelle, med traumet, som er utilgængeliggjort. Det reelle er sandhedens sted i den hysteriske diskurs, som hele tiden giver sig til kende som noget andet. Hysterien er på en gang en evindelig repetition af og en evindelig flugt fra en kæde af metonymisk forbundne erindringsspor, men denne modsætningsfyldte bevægelse er altså altid topisk forflyttet; traumet kan ikke nås og kan ikke opløses, men bliver hele tiden symboliseret og hele tiden repeteret. Bronfen siger, at det at være traumatiseret er at være "possessed by an image or an event $« i^{26}$ men billedets »det der var«, negativet, kan aldrig kaldes frem; det kan blot pege på det og, som fritsvævende repræsentation, reproduceres endeløst; derfor, siger Bronfen, modsætter hysterien sig lukning, og "the hysteric conversion seeks interminability «. ${ }^{27}$ Den er et resultat af en række disparate fragmenters sammenbinding, forskudte erindringsbilleder, forskellige fantasier, de somatiske udtryk m.v. I denne sammenhæng hævder Bronfen også, at den hysteriske symptomdannelse (til forskel fra f.eks. paranoiaen) netop ikke skriver en sammenhængende historie; traumet kan ikke narrativiseres.

\footnotetext{
25. Op.cit., p. 40.

26. Ibid., p. 35

27. Ibid., p. 32.
} 
I forordet til bogen benævner Bronfen traumet som en knude af erindringsspor, der som en vandrende fremmed krop, bogens centrale metafor, hjemsøger psyken, vandrende fordi hysteriens symptomer er mangfoldige og hele tiden skiftende, søgende sig stadigt nye former på kroppen, former som i sidste ende alligevel blot er iøjnefaldende gentagelser. Hun benævner hysteriens sprog med begreberne overdrevet, excessivt, desorienterende omskifteligt, overdetermineret, og hun taler også om det som på én gang udviskende forskelle og etablerende distinkte forskelle, oscillerende mellem yderpunkter.

Hvordan ser jeg da mere konkret Magnolia som hysterisk realisme? Først og fremmest er jo dette imposante, 182 minutter lange værk hysterisk langt. Eller sagt på en anden måde: Som det hysteriske sprog kan filmen ikke slutte, og næsten emblematisk kan Aimee Mann sammen med filmens karakterer synge, at »It's not going to stop« - Till you wise up« - siger fra. Men det er præcis, hvad personerne ikke kan eller kun kan med det største besvær. I hvert fald lader filmen det være åbent, om de kan; om filmens børn og barnlige sjæle kan hjælpes, Claudia, Linda, Stanley og Frank. Filmen består af en række narrative tråde, der for fleres vedkommende ender åbent, og den tidslige progression er ujævn. Som et spejl af det overordnede narrativ unddrager quiz show'et sig tilsvarende slutning eller lukning hvilket jo ellers er hele pointen i et quiz show; det har normalt et tydeligt narrativt forløb omkring en antagonistisk struktur, der her destrueres af en dreng, der skal tisse. Der skal være en vinder og en taber, men da show'et afbrydes, må en af de voksne konkurrencedeltagere i denne kamp mellem børn og voksne spørge, hvem der vandt.

Den lange film er parataktisk bygget op. Sammenhængen mellem indstillinger er etableret via forskellige former for lighedssættende analogier; f.eks. klippes der fra en indstilling af Frank på en bar i en tv-reklame for hans kurser til en indstilling af Claudia på en bar, eller der klippes fra et umotiveret nærbillede af nøglerne i Jims bil (efter at han har hentet Claudia til deres date) til et nærbillede af Donnies nøgler på køkkenbordet. Men nøglerne refererer ikke til tolkningsnøgler. Billederne er konkrete. De er det, vi ser og føjes blot sammen, uden at de tildeler hinanden betydning, og dermed er sammenføjningsmulighederne og repetitionsmulighederne legio. Repetitioner findes derudover knyttet som en struktur til personerne - i Jimmys uendelige gentagelser som quiz-vært (kortene der har været de samme i 30 år), i Claudias repetitive indtagelse af coke, i Lindas evigt gentagne »fuck«. Og endelig findes den i Aimee Manns sange, hvis genkommende lyriske figur er gentagelsen. 
Der er ikke blot tale om en horisontal, visuel paratakse, men også en vertikal, auditiv, paratakse, i de mange forskellige tekstformer, der ligger oven i hinanden og danner et disparat lyd tæppe uden ordnende hierarki; dialog, lyd fra apparater i det diegetiske rum, både on og off screen og underlægningsmusikken - først og fremmest Aimee Mann's smukke depressive sange. Men pointen er også her, at de forskellige lydlag ikke føjer sig ind i en betydningsmæssig sammenhæng, eller at underlægningsmusikken forklarende eller uddybende understøtter billedsiden (udtrykker det personerne ikke selv kan udtrykke som i melodramaet). Som Paul Thomas Anderson selv har sagt, at han "sat down to write an adaptation of Aimee Mann songs «, ${ }^{28}$ fremstår den indledende lange sekvens lige så meget som en musikvideo - en illustration af Mann-sangen »One« - som at sangen fortolkende skal henlede vores opmærksomhed på, at denne film handler om ensomme mennesker. Og lange monologer, som Earls historie om Lily, høres på lydsiden, samtidig med at billedsiden fortsætter med at bevæge sig mellem de andre personer, som også tilfører lydsiden diegetisk, nedtonet, lyd. I den forstand etablerer filmen et audiovisuelt hysteri, et excessivt forbrug af billeder og lyd, der springer fra den ene person til den anden uden anden motivation end en stilistisk og med historier, der næsten synes at falde over hinanden, fordi Anderson manipulerer med tidsforholdene mellem de forskellige sekvenser. Endelig bevæger filmen sig også hæmningsløst mellem de forskellige niveauer i udsigelsen, dvs. mellem forskellige beskuerpositioner, der især i tråden omkring quiz-showet hele tiden skifter.

Som hysterien taler forskudt igennem de kropslige symptomer, findes der i beskrivelsen af Claudia en række eksempler på forskydninger, som knytter sig til det ikke-repræsenterbare sår, men giver sig udslag i sproget ikke som fortalelser, men som næsten-sandheder, der ikke bliver erkendt som sådanne. Da politimanden Jim, hidkaldt af klager over larm og skænderier i Claudias lejlighed, begynder at tale til hende om »domestic abuse situations«, om kvinder der ikke vil fortælle om vold mod deres krop og så, som han siger, har vi en »187«- og spørger hende, om hendes »boy friend « generede hende, så er han tæt på sandheden. Claudia bliver ved med at benægte hårdnakket, at det var hendes boy friend, hun skændtes med. Det er umiddelbart sandt, for det var hendes far, hun skændtes med. Men senere skal det vise sig, at han måske alligevel var en 'boy friend'. Den metonymiske forskydning er det moderne sprogs rationale - som den sorte rap-dreng benytter sig af, når han i forskudt form rapper sin viden om, hvem

28. I en lille tekst, han har skrevet til tekstarket til soundtracket fra filmen med Aimee Mans sange. 
der myrdede manden i Marcias skab. Men Jim forstår ikke forskydninger. Når Claudia klikker med kæben og siger, at det hedder TMJ, siger han, hvorfor ikke kalde det, det er, »clicking jaw«. Idealet er, som Claudia siger, at »I'll tell you everything and you tell me everything and maybe we can get through all the piss and shit and lies that kill other people«. Men så kan hun heller ikke mere; for det sprog, der er mærket af traumet, må altid tale udenom. Derfor må hun først gå ud på wc'et og snuse en bane coke, og da hun kommer ind igen spørge, om han vil "object to never seeing each other again«som der står i Aimee Mann-sangen »Deathly« med endnu en af filmens karakteristiske sideordninger af forskellige udsigelsespositioner.

Karakteren Claudia er tegnet som hysteriker, med en evigt dirrende krop, den klikkende kæbe, den excessive inhalering af coke og noget, der ikke kan komme frem, men som måske har med incest at gøre. Men filmen har en anden, ligeså hysterisk karakter, som findes i den modsatte ende af personspektret - det er nemlig Frank. Tilsyneladende befinder Frank sig ikke i nogen repræsentationskrise. Der er ingen slinger i valsen, »I am what I believe, I do as I say«, siger han, proklamerende at hans ydre svarer til hans indre - der er ingen forskydninger i hans sind. Men pointen er, at hans hele ydre gestalt er transformeret til en »wandering foreign body«. Det er ganske tydeligt, da vi ser ham iscenesætte sig selv i et overdetermineret tableau i begyndelsen af en af sine workshops: Til de herostratisk berømte toner fra Also Sprach Zarathustra af Richard Strauss introduceres han i en silhouet, der bærer mere end tydelige mindelser om chimpansens - og skulle man ikke have set denne lighed, peger musikken på den - den blev jo som bekendt brugt i indledningssekvensen til Stanley Kubricks Rumrejsen år 2001. ${ }^{29}$ Så det, der hos Frank T. J. Mackey dementeres som en repræsentationskrise ("malady of representation«), bliver det alligevel - netop fordi Frank falder sammen med sin hysteriske performance. Frank dementerer, at fortiden eksisterer; "the most useless things is that which is behind me« er et af hans slagord. Men som filmen gentager flere gange, og som jeg tidligere har citeret: "We may be through with the past, but the past ain't through with us«. Derfor drejer filmens tema sig også i høj grad om at »suffer from reminiscenses « (det er således Freud omtaler hysterikeren) - om at lide af eller lide under - erindringer.

Set fra én vinkel kan man sige, at sætningen om fortiden og nutiden udtrykker hysterien i en nøddeskal; umuligheden af at omfatte eller nærme

29. En af mine studerende har gjort opmærksom på den indirekte sammenhæng, der også knyttes til Eyes Wide Shut i sammenknytningen af Tom Cruise og Stanley Kubrick. En anden har gjort opmærksom på, at Frank T. J. Mackey også er en figur i Don DeLillos roman Libra fra 1988. 
sig traumet, som på sin side hele tiden giver sig til kende i en bevægelse, der konstruerer et liv som et ikke-lineært forløb. Fra en mere umiddelbar vinkel bliver sætningen til en indsigt hos flere af personerne, når de konfronteres med døden, og det giver dem en ustyrlig trang til at skrifte, til at blive fri for skyld, fortælle den anden eller en anden sandheden, om utroskab, om svigt, om fejltagelser. Således iscenesætter filmen i forskudt form, nemlig i form af konkrete historier om skyld og soning og tilgivelse, fortællingen om den menneskelige skrøbelighed og fejlbarlighed, knyttet til kroppen og begæret. Så sandheden er da også Earls rallende kvalfulde snak før døden om »this fuckin life« og hans afsluttende fortvivlet halvkvalte gentagne "what did I do?«

Filmen har således en smuk morale, som fastholder skrøbeligheden i eksistensen og taler om, at der ingen absolutter er, men heller ingen oplagte løsninger; den bliver til sidst udtrykt gennem politimanden Jim, der funderer over, hvad man kan tilgive, for det er noget af det svære i livet at finde ud af det: „Sometimes people need a little help. Sometimes people need to be forgiven. And sometimes they need to go to jail«.

Men hvad så med frøerne, der plasker og splatter ned i hobetal i filmens sidste sekvens? Man kan spørge sig, om de dementerer filmens realisme, eller den godtagne oplevelse af filmen som realistisk, ved i sidste øjeblik at påkalde sig en læsning som traditionel, bibelsk allegori. Det er svært at undgå at tænke på Bibelens historie om Egyptens ti plager fra Det gamle Testamentes Anden Mosebog (frøerne er den anden plage), også selv om vi måske er blevet mindet om den tomme transcendens gennem de genkommende billeder af himlen. Eller er det snarere sådan, at allegorien som moderne tankefigur giver god mening i denne sammenhæng, og at frøerne som excessivt udtryk kan ses som en direkte påkaldelse af denne figur sammenholdt med den gentagede sætning om historien, der ikke er færdig med os, ligesom den hysteriske »skrift« hele tiden blander sig med nutiden i de særeste, løsrevne former.

Filmen modsætter sig dog også enhver læsning af frøerne som andet end det, de ligner, og samtidig som noget, der ikke falder uden for filmens realistiske mise-en-scène. Donnie og Jim ikke engang omtaler frøerne, men splatter besværet hen over dem til Donnies bil, hvor Donnie med den største selvfølgelighed fjerner dem fra forruden. Deres slimede paddeform, hvis tunge slimethed understreges af lydsiden, gør dem til meget prosaiske, fysiske fremtrædelser, tunge af realitets-effekt i deres påtrængende tilstedeværelse, rammende os med virkelighed. Derfor kan man også se dem som et inverteret symbol, et symbol der dementerer sig selv som et sådant som netop ikke henviser til noget fast. Anderson vender symbolet på hove- 
det - frøerne kommer ganske vist fra himlen, men den er tom, og de er tunge af materie. Således kan man endelig også se disse digitalt frembragte frøer som en underfundig kommentar til spørgsmålet om digitalitet og realisme. Det paradoksale er, at det, der aldrig har været, slår os mest med realitet.

Traumet opløses ikke. Vi får ingen endegyldige sandheder til slut. Filmen kan ikke slutte, og dog må den slutte, og den eneste måde den kan slutte på, synes Paul Thomas Anderson at sige, er ved hjælp af en bevidst naiv »happy ending«. I morgengryet har Claudia fået hjælp af sin mor, og Bill dukker op hos hende igen. Og hun kigger ud mod kameraet, ud på tilskueren, som for at spørge, om virkeligheden er sådan.

\section{Afslutning}

Magnolia går mere eksplicit i dialog med den klassiske realismes elementer end Happiness, idet den vender størrelser som determinationsforhold, et autoritativt syn på årsags-virkningsforhold og fortidens både destruktive og rensende genkomst i nutiden på hovedet. Magnolia forholder sig til en moderne virkelighed som en medievirkelighed, med streg under både medie og virkelighed. Medierne influerer eksplicit på flere af personernes liv, nøjagtigt ligesom andre ting gør det. Således bliver metaaspektet i Magnolia et realistisk element i filmen, ikke et meta-fiktionelt - det åbner fiktionen i stedet for at lukke den. I Happiness kan manglen på medier i personernes hverdag omvendt ses som en blandt flere bestræbelser i filmen på at afkontekstualisere personerne og herigennem beskrive en depressiv realitet uden nåde, uden orienteringsmuligheder. De to film har den flimrende narration til fælles, den konkrete, ikke-hierarkiske klipning mellem en række personer, der er tættere eller løsere forbundet med hinanden, en tekstform der hviler på et sideordningens princip. Denne struktur kan ses som en opfattelse af, at det ikke er muligt at sammenfatte virkeligheden i ét syn; men paradoksalt nok kan Happiness da med sin cool blanding af groteske, superrealisme og konsekvente overfladerealisme ses som den mest autoritativt fortalte af de to film; den ved konsekvent, at den ikke kan vide, hvordan den skal sammenfatte et mønster i virkeligheden. De to film er realistiske på meget forskellige måder, men de ekspliciterer begge en forestilling om sig selv som film, der på én gang iscenesætter og forholder sig til den sociale virkelighed. Det spændende ved dem er, at de på forskellig vis gebærder sig i et felt, hvor realisme som filmform ikke har klare demarkationslinjer mod andre -ismer og ikke er transparent, som tydeligt skilter med sine æstetiske 
virkemidler og sig selv som tekster, men som ikke desto mindre tilbyder en oplevelse af virkelighed, realitetseffekt. Realisme bliver i forhold til de to film ikke et spørgsmål om mimesis, men om, hvad der i sidste ende opleves som genkendelig virkelighed. 